J. Clin. Chem. Clin. Biochem.

Vol. 28, 1990, pp. 519-525

(C) 1990 Walter de Gruyter \& Co. Berlin - New York

\title{
Variations in Apolipoproteins Serum Amyloid A, A-I, A-II, and C-III in Severely Head-Injured Patients
}

\author{
By Rachid Saïle ${ }^{1}$, Ouafae Kabbaj ${ }^{2}$, Sophie Visvikis ${ }^{3}$, Josiane Steinmetz $^{3}$, A. Steinmetz $^{1}$, G. Férard ${ }^{2}$, \\ J.-C. Fruchart ${ }^{1}$ and P. Métais ${ }^{2}$ \\ ${ }^{1}$ Service de Recherches sur les Lipoprotéines et l'Athérosclérose (SERLIA), INSERM U.325, Institut Pasteur \\ de Lille, Lille, France \\ ${ }^{2}$ Laboratoire de Biochimie Appliquée, UER des Sciences Pharmaceutiques, Université Louis Pasteur, Strasbourg, \\ France \\ ${ }^{3}$ Laboratoire de Biologie Clinique, Centre de Médecine Préventive, Vandoeuvre Nancy, France
}

(Received June 6, 1989/May 18, 1990)

\begin{abstract}
Summary: In five severely head-injured patients we determined the plasma concentrations of apolipoproteins serum amyloid A, A-I, A-II, C-III, and B, prealbumin and C-reactive protein on day 1, 5, 10 and 15 after head injury where possible. A dramatic increase in apolipoprotein serum amyloid A up to a mean plasma level of $0.764 \mathrm{~g} / \mathrm{l}$ was accompanied by a considerable decrease in apolipoprotein A-I, apolipoprotein A-II and apolipoprotein C-III concentrations. The variations observed by immunological methods were confirmed by two-dimensional gel electrophoresis performed on plasma and different lipoprotein fractions. In addition to its association with high density lipoproteins, apolipoprotein serum amyloid A was also found with lipoproteins of low and very low density. Two-dimensional electrophoresis also showed the presence of several different serum amyloid A-peptides not seen in plasmas from healthy subjects. We propose that apolipoprotein serum amyloid A may be responsible for the decrease of the main HDL apolipoproteins in head-injured patients.
\end{abstract}

\section{Introduction}

The acute phase response is a systemic reaction to infectious and non-infectious agressive processes. Multiple physiological adaptations occur, including changes in the hepatic synthesis of a number of plasma proteins termed acute phase reactants (1). During inflammation, the apolipoprotein composition of serum high density lipoprotein particles changes markedly. The major apolipoprotein A-I is partially displaced by a protein known either as apolipoprotein $\mathrm{S}(2-4)$ or, more commonly, as apolipoprotein serum amyloid A (5-9). Serum amyloid A and C-reactive protein are the most characteristic and sensitive acute phase reactants $(10,11)$. The synthesis of apolipoprotein serum amyloid $\mathrm{A}$, which occurs predominantly in the liver, increases 500-1000-fold following an inflammatory stimulus $(10,12)$. Macrophage/monocyte-derived interleukin 1 has been shown to be a potent inducer of serum amyloid A synthesis in hepatocytes $(13-16)$. The mechanism by which interleukin 1 stimulates the synthesis seems to be a direct modulation of the expression of the genes coding for serum amyloid A (17). Recent studies suggest that interleukin 6 and tumour necrosis factor also induce acute phase protein synthesis $(18,19)$. Up to six isoforms of serum amyloid $\mathrm{A}$ have been identified with different isoelectric points ranging between $\mathrm{pH}$ 5.2 and $7.4(20)$.

Apolipoprotein serum amyloid $\mathrm{A}$ is transported in association with high density lipoprotein and may represent as much as $25-50 \%$ of the HDL protein $(4,20-22)$. The effect of the acute response on HDL is of interest since serum amyloid A catabolism rate is affected by binding to lipoproteins (23). Malmendier et al. $(24)$ and others $(6,25)$ have shown that HDLserum amyloid $\mathrm{A}$ seems to be metabilized more rap- 
idly than other HDL particles. The particles also containing A-I (Lp A-I: serum amyloid A) have a much slower turnover rate than the particles not associated with apolipoprotein A-I (Lp serum amyloid A) (24).

Several laboratories have recently investigated the properties of HDL from a variety of inflammatory disorders $(26-30)$. All reported a decrease of apolipoprotein A-I concentration. These studies involved comparisons of HDL from normal subjects with HDL isolated at a single time-point from patients with a spectrum of diseases and severity. Effects related to duration and intensity of the acute phase response were not evaluated. The fact that lowered HDL concentrations have been observed in some studies and not in others may be due to differences in the severity of the acute phase responses, or related to the delay in obtaining the plasma after the onset of inflammation. Recently, we have observed an approximate $50 \%$ decrease in apolipoproteins A-I, A-II and C-III concentrations after severe head injury (31). The purpose of the present study was to investigate the possible connection of these apolipoprotein changes with apolipoprotein serum amyloid A and its lipoprotein distribution in head-injured patients at different times after the injury.

\section{Materials and Methods}

Patients

Five adult patients ( 3 men, 2 women) were admitted to "Centre d'Orthopédie et de Traumatologie de Strasbourg" for isolated severe head injury. They were apparently healthy before trauma. The patients were daily receiving during their hospitalization a continuous isocaloric enteral infusion of Nutrison ${ }^{\circledR}$ (Nutricia, Holland). This infusion consisted of $36 \%$ lipids, $16 \%$ proteins and $48 \%$ carbohydrates in terms of calories and was supplemented with vitamins and minerals. Of the five patients, two died on day ten after cranial injury, the others survived. Blood samples were collected from each patient on day 1, 5, 10 after injury, also on day 15 from the survivors. Samples were centrifuged and the plasmas were stored at $-20^{\circ} \mathrm{C}$ until analysis. In these conditions, no significant lipid or apolipoprotein modifications were observed.

\section{Lipoprotein fractionation}

Lipoprotein fractions (VLDL, LDL, HDL) were isolated from fresh plasma samples by sequential preparative ultracentrifugation (32) in a Beckman model L5-50 ultracentrifuge, using a Beckman $50 \mathrm{Ti}$ rotor. Fractions were collected and dialysed against a $0.15 \mathrm{~mol} / 1 \mathrm{NaCl}$ solution containing $\mathrm{Na}_{2}$ EDTA $(1 \mathrm{mmol} / \mathrm{l}) \mathrm{pH} 7.4$ for $24 \mathrm{~h}$ at $4{ }^{\circ} \mathrm{C}$. The protein concentration of each fraction was determined as described by Bradford (33).

Two-dimensional polyacrylamide gel electrophoresis

Two-dimensional electrophoresis was carried out essentially as described (34) with some modifications for application to apolipoproteins $(35,36)$. Apolipoproteins were separated in $8 \mathrm{~mol} / \mathrm{l}$ urea and $20 \mathrm{~g} / \mathrm{l}$ Nonidet $\mathrm{P} 40$ in the first dimension, and $10 \mathrm{~g} / \mathrm{l}$ SDS in the second dimension. Plasma proteins $(200 \mu \mathrm{g})$ were applied to the first dimension gel. For VLDL, LDL, HDL analysis, the amount of applied proteins was $6.4,4.8$ and 12.8 $\mu \mathrm{g}$ respectively.

\section{Apolipoprotein determinations}

Apolipoprotein serum amyloid $\mathrm{A}$ was quantitated using a sandwich ELISA technique (37). Briefly, pure apolipoprotein serum amyloid $\mathrm{A}$ was used as primary standard. The antisera were prepared by injecting New Zealand White rabbits with two chemically synthesized short fragments of apolipoprotein serum amyloid A1 corresponding to residues 58-69 and 95-104 of apolipoprotein serum amyloid A covalently linked to tetanus toxoid with glutaraldehyde. The antibodies recognized both their corresponding peptides and apolipoprotein serum amyloid $A$, and were used in the ELISA assay (37). Apolipoprotein CIII was also quantitated by sandwich ELISA as previously described (38). The apolipoprotein A-I, apolipoprotein A-II and apolipoprotein $B$ concentrations were measured by electroimmunoassay using reagents purchased from Sébia (Issy-lesMoulineaux, France) (39).

\section{CRP and prealbumin deteminations}

C-reactive protein concentrations were determined by immunonephelometry as previously described (40). Prealbumin (transthyretin) was assayed with a monospecific antibody ( $\mathrm{Hy}-$ land Division of Travenol Laboratories, Plaisir, France) diluted with a solution containing $40 \mathrm{~g}$ of polyethylene glycol 6000 (Merck, Hohenbrunnen, FRG) and $150 \mathrm{mmol}$ of $\mathrm{NaCl}$ per litre on a laser PDQ nephelometer Hyland (41).

\section{Results}

Five head-injured patients were monitored for 15 days after injury by apolipoprotein measurements on day 1, 5, 10 and 15 (two patients died after day 10, thus no data exist for these subjects for day 15). The results are summarized in table 1. Apolipoprotein A-I and A-II concentrations decreased markedly, while apolipoprotein C-III decreased to a lesser extent and began to rise again on day 15 . Whereas apolipoprotein A-I continued to decrease until day 10 , the levels of apolipoprotein A-II and C-III had become constant by day 10 , or even started to increase again. In contrast, apolipoprotein B concentrations did not change significantly. Apolipoprotein serum amyloid A and C-reactive protein increased immediately after injury. Whereas apolipoprotein serum amyloid A was already increased on the first day and showed a peak on day five, the C-reactive protein increase was retarded, reaching maximal levels on day 10 . Prealbumin measured along with the apolipoprotein parameters also decreased in the post injury period.

To further determine whether the increase in plasma levels of apolipoprotein serum amyloid A was due to a preferential increase of one of the plasma isoforms, two-dimensional electrophoresis of plasma was car- 


\section{Chemistry and Biology of Pteridines 1989}

\section{Pteridines and Folic Acid Derivatives}

Proceedings of the Ninth International Symposium on

Pteridines and Folic Acid Derivatives

Chemical, Biological and Clinical Aspects

Zurich, Switzerland, September 3-8, 1989

Editors: H.-Ch. Curtius, S. Ghisla, N. Blau

$1990.17 \mathrm{~cm} \times 24 \mathrm{~cm}$. XXXVI, 1.340 pages. With numerous illustrations. Hardcover. DM 450,- ISBN 3110121999

This volume contains a combination of review articles and research papers describing the most recent research work.

Contents in Brief

Chemistry of Pterins and Folates - Analysis of Pterins and Folates · Biosynthesis and Biochemistry of Pterins · Tetrahydrobiopterin Deficiency · Pterins, Various · Biology of Pterins · Tetrahydrobiopterin-Dependent Monooxygenases · Folates (Dihydrofolate Reductase - Thymidylate Synthase - Methionine Synthase - Enzymology and Metabolism - Folates in Endogeneous Purine Metabolism - Folates, Various) - Antifolates (Deazaderivatives - Methotrexates - Various Antifolates Transport and Absorption of Folates and Antifolates) - Subject Index

Also available

Chemistry and Biology of Pteridines

Editor: W. Pfleiderer

1975. VII, 949 pages. DM 190,-

Chemistry and Biology of Pteridines

Pteridines and Folic Acid Derivatives

Editor: J. A. Blair

1983. XXXVI, 1.070 pages. DM 280,-

Chemistry and Biology of Pteridines 1986

Pteridines and Folic Acid Derivatives

Editors: B. A. Cooper, V. M. Whitehead

1986. XXVIII, 1.048 pages. DM 380,-

Prices are subject to change without notice 


\title{
Biochemistry of Peptide Antibiotics
}

\section{Recent Advances in the Biotechnology of $\beta$-Lactams and Microbial Bioactive Peptides}

\author{
Editors: Horst Kleinkauf, Hans von Döhren
}

1990. $17 \mathrm{~cm} \times 24 \mathrm{~cm}$. XIV, 522 pages. With numerous illustrations.

Hardcover. DM 310,-; approx. US \$ 182.00 ISBN 3110119285

Peptide Antibiotics, $\beta$-Lactams and bioactive Peptides have maintained a significant position in research and applications. Classical Cyclopeptides like Gramicidin S, Cyclosporin, Bleomycins, the various Proteinase Inhibitors, Siderophores, new $\beta$-Lactams and Vancomycin type Glycopeptides are presented from their representative leads in basic research in biosynthesis, genetics, chemistry, pharmacology, and biotechnology. The main developments of the last years have been reviewed, and structural information on naturally occurring Peptides has been compiled.

This monograph will serve researchers in the Peptide field as source and reference book.

\section{From the Contents}

Bioactive Peptides - Recent Advances and Trends - Gramicidin S Synthetase - Formation on $N$ methylated Peptide Bonds in Peptides and Peptidols - Peptide Bond Synthesis by Enzyme-Catalyzed Acyl-Transfer - Genetics of Siderophore Biosynthesis and Transport - Discovery of new $\beta$-Lactam and $\beta$-Lactam like Antibiotics from Bacteria - Glycopeptide Antibiotics of the Vancomycin Group · Peptide Phytotoxins from Plant Pathogenic Fungi - Chemical Synthesis and Bioactivity of Gramicidin S and Related Peptides - Cyclosporine: Synthetic Studies, StructureActivity Relationships, Biosynthesis and Mode of Action - Biosynthesis and Chemical Synthesis of Bleomycin - Small Molecular Protease Inhibitors and Their Biological Effects - Directed Biosynthesis of Neoviridogriseins - Biochemical Genetical and Biotechnical Aspects of Antibiotic Production via Immobilised Biocatalysis - Compilation of Peptide Structures - A Biogenetic Approach · Contributors · Index

Price is subject to change without notice

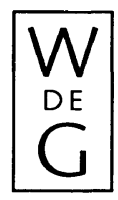

de Gruyter Berlin · New York 
ried out during the study. Figure $1(\mathrm{a}-\mathrm{c})$ shows the sequence of changes in plasma proteins from a representative patient. In the area which corresponded to apolipoprotein serum amyloid $\mathrm{A}$ isoforms according to their physicochemical properties (isoelectric $\mathrm{pH}$, apparent relative molecular mass), two spots were observed at day 1 (fig. 1a). The number and intensity of these spots were increased mainly on day 5 (fig. 1b). At this time six spots were detectable, whose intensity decreased on day 10 (fig. 1c). Figure 1d shows the pattern for a healthy adult; for the same molecular mass, two spots were apparent which might correspond to the two ususal apolipoprotein serum amyloid $\mathrm{A}$ isoforms. Thus the increase of apolipoprotein serum amyloid $\mathrm{A}$ in plasma was accompanied by the appearance of additional isoforms usually not detected in plasma. On day 5 , only two major apolipoprotein serum amyloid A isotypes were detectable in LDL and VLDL. In contrast, the number and intensity of apolipoprotein serum amyloid A spots were more pronounced in HDL (fig. 2). Thus twodimensional gel electrophoresis gave some information additional to that obtained by the immunological methods.

\section{Discussion}

Apolipoprotein serum amyloid A is normally present in trace amounts in human plasma but the concentration increases up to 1000 -fold as part of an acute phase response during trauma (27). A tremendous increase in apolipoprotein serum amyloid $\mathrm{A}$ has also been observed in the patients studied here with severe head injury.

Several studies have shown that the increase of apolipoprotein serum amyloid A concentration is associated with a low level of apolipoprotein A-I and apolipoprotein A-II or HDL lipids $(27,29)$. In this study we confirm the "negative acute phase reactant" role of apolipoprotein A-I (30) after head injury and also report a considerable decrease in apolipoprotein A-II and apolipoprotein C-III. Normally apolipoprotein serum amyloid $\mathrm{A}$ in plasma is found associated with lipoproteins, especially with those of high density (5). Furthermore, isolated apolipoprotein serum amyloid A polymorphic forms, like other apolipoproteins, have been reported to disrupt multilamellar dimyristoylphosphatidylcholine liposomes and to generate bilayer discs (42). In vitro it has been demonstrated that apolipoprotein A-I can be displaced by apolipoprotein A-II from the HDL surface in such a way that apolipoprotein A-II is transfered from the solvent phase onto the HDL surface in a concentration-dependent fashion (43). Apolipoprotein serum amyloid 

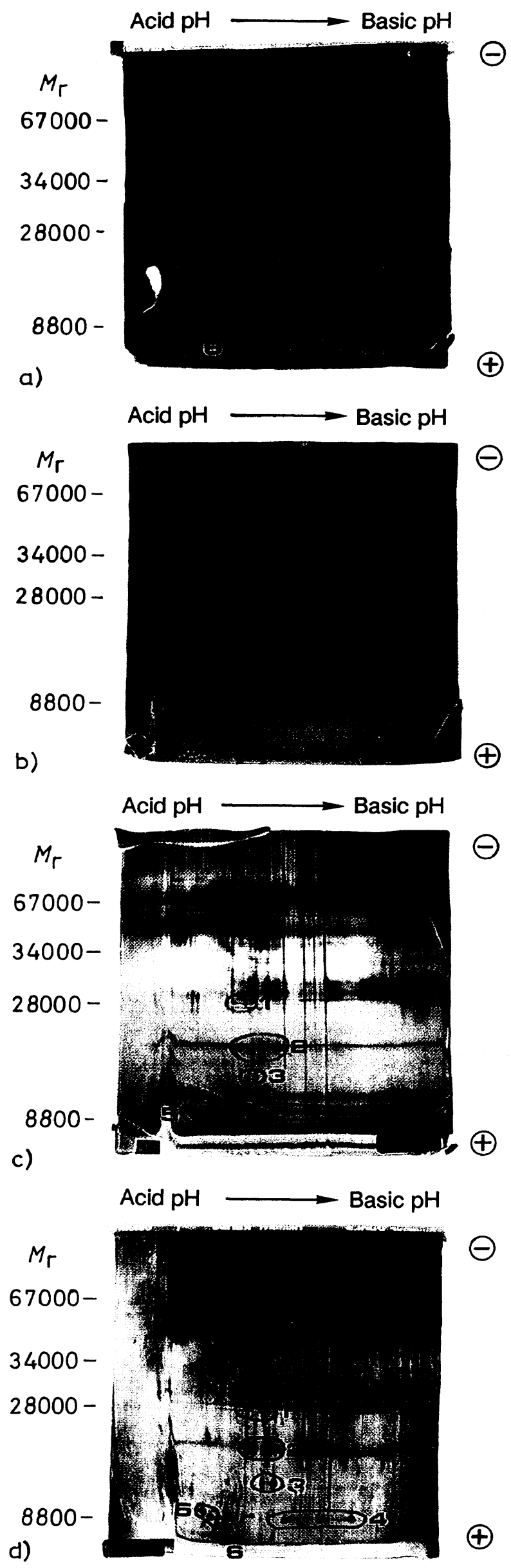

$\oplus$
Fig. 1. Two-dimensional polyacrylamide gel electrophoresis of plasma from one head-injured patient on day 1 (a), 5 (b) and 10 (c) after injury in comparison with control plasma (d).

1: apolipoprotein A-I

2: $\alpha_{2}$ chain of haptoglobin,

3: prealbumin,

4: serum amyloid $A$,

5: apolipoprotein $\mathrm{C}$,

6: apolipoprotein A-II.
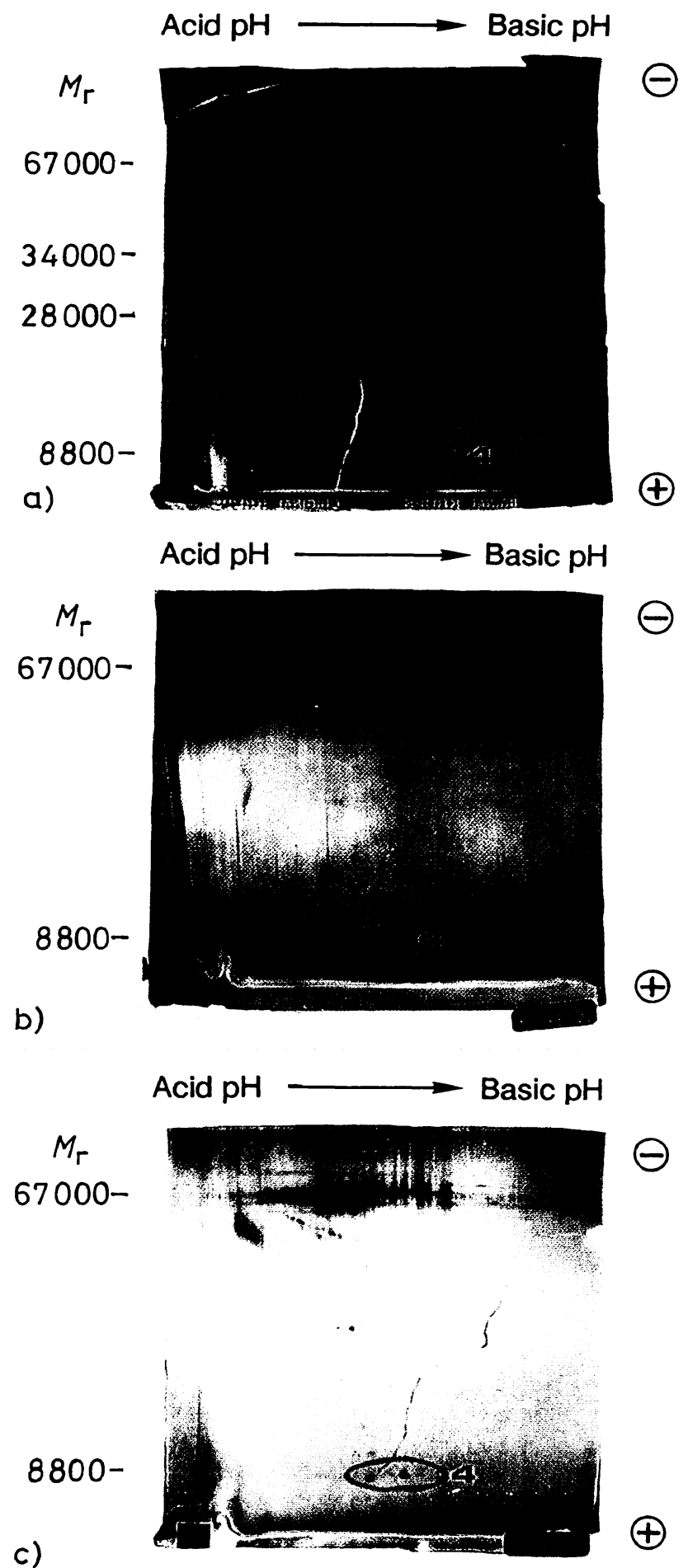

$\oplus$

Fig. 2. Two-dimensional polyacrylamide gel electrophoresis of HDL (a), LDL (b), and VLDL (c) isolated from the plasma on day 5 after head injury (same plasma as in figure 1). For details see legend of figure 1. 
A also seems to be capable of displacing apolipoprotein A-I or A-II from lipoprotein particles in a very similar, concentration-dependent manner. It was concluded that apolipoprotein serum amyloid $\mathrm{A}$ had a higher affinity than apolipoprotein A-I and A-II for HDL particles (29). Several groups have shown that the association of apolipoprotein serum amyloid A mainly with denser $\mathrm{HDL}_{3}$ particles increased their diameter to form particles that resemble $\mathrm{HDL}_{2}$ in size $(28,29)$. The addition of serum amyloid A to HDL resulted in particles comprising up to $80 \%$ of serum amyloid A in their protein moiety (29).

One mechanism of lowering of HDL apolipoproteins A-I, A-II and C-III in our study could be their displacement from HDL particles by serum amyloid A. The displaced apolipoproteins would then have an increased catabolism. Several laboratories have postulated that serum amyloid A was incorporated into HDL and displaced the normal HDL protein. This theory is based on two observations. Firstly, serum amyloid A can represent a high proportion of the HDL proteins without a proportional increase in the total protein content (9). Secondly, the incorporation of serum amyloid $\mathrm{A}$ into HDL and the concomitant displacement of apolipoprotein A-I have been demonstrated in vitro (29). Serum amyloid A comprised as much as $80 \%$ of the HDL protein. Only apolipoprotein A-I was displaced, and the A-II and C protein content did not change (29).

A further mechanism, simultaneously responsible for the decrease of HDL apolipoproteins, might be a reduction of their synthesis during the acute phase response. Hepatic synthesis of several plasma proteins is known to decline during the acute phase response. Bausserman et al. (9) suggested that low HDL levels during acute phase response could be due to reduced apolipoprotein synthesis rather than displacement by serum amyloid A. Baumann et al. (44) showed a decreased rate of apolipoprotein A-I synthesis in primary hepatocytes isolated after initiation of acute inflammation. Also Lowell et al. (45) have reported that the levels of albumin and apolipoprotein A-I mRNA decreased 2-fold in cultured rat hepatocytes after endotoxin administration. Thus several mecha- nisms, including a direct effect of interleukins 1 and/ or 6 , may be responsible for the decrease in normal HDL apolipoproteins in head-injured patients (46, 47). Studies of HDL apolipoprotein synthesis by the intact organism and by the liver will be required to demonstrate reduced apolipoprotein production during the acute phase response.

Apolipoprotein serum amyloid A was shown in several studies to be a heterogeneous plasma protein $(20$, $26,48-50)$. Sequencing data from different apolipoprotein serum amyloid $\mathrm{A}$ isoforms are compatible with the hypothesis that there exist at least two genes coding for apolipoprotein serum amyloid A $(51,52)$. cDNA-derived sequences also confirm this view (53, 54). All investigations agree that plasma contains two dominating apolipoprotein serum amyloid A forms (serum amyloid A1 and A2) and up to four minor peptides. Under physiological conditions only apolipoprotein serum amyloid A1 and apolipoprotein serum amyloid A2 are detectable in trace amounts in human plasma. During acute phase responses, not only apolipoprotein serum amyloid A1 and apolipoprotein serum amyloid A2, but also the other isoforms may increase. In our study, head injury led to the multiplication and intensification of certain spots which may correspond to apolipoprotein serum amyloid A isoforms. Present results are compatible with a proportional increase of all isoforms revealing certain spots already present but in indetectable amounts. We also showed that mainly apolipoprotein serum amyloid A1 and apolipoprotein serum amyloid A2 were also associated with LDL and VLDL, whereas the remaining isoforms seem to associate predominantly with HDL. Two dimensional gel electrophoresis during the acute phase response could thus be a tool to monitor the induction of different isoforms in various diseases and to identify possibly amyloidogenic apolipoprotein serum amyloid A forms.

In conclusion, head injury leads to an acute phase response similar to other inflammatory processes; this response includes the appearance of several detectable isoforms of apolipoprotein serum amyloid $\mathrm{A}$ in plasma.

\section{References}

1. Kushner, I., Volanakis, J. E. \& Gewurz, H. (1982) Creactive protein and the plasma protein response to tissue injury. Ann. N. Y. Acad. Sci. 389, 1.

2. Malmendier, C. L., Christophe, J. \& Amerycks, J. P. (1979) Separation and partial characterisation of new apoproteins from high density lipoproteins. Clin. Chim. Acta 99, $161-$ 176.
3. Malmendier, C. L., Paroutand, P. \& Amerycks, J. P. (1980) Partial amino acid sequence of three new apolipoproteins isolated from human high density lipoproteins. FEBS Lett. $109,43-44$.

4. Malmendier, C. L. \& Amerycks, J. P. (1982) Apoprotein S, a family of human serum lipoprotein polypeptides. Atherosclerosis $42,161-172$. 
5. Benditt, E. P. \& Eriksen, N. (1977) Amyloid protein SAA is associated with high density lipoproteins from human serum. Proc. Natl. Acad. Sci. USA 74, 4025-4028.

6. Parks, J. S. \& Rudell, L. L. (1983) Metabolism of the serum amyloid protein (SAA) in high density lipoproteins and chylomicrons of nonhuman primates (vervet monkeys). Am. J. Pathol. 112, 243-249.

7. Husebekk, A., Skogen, B. \& Husby, G. (1987) Characterisation of amyloid protein $\mathrm{AA}$ and $\mathrm{SAA}$ as apolipoprotein of high density lipoproteins (HDL). Scand. J. Immunol. $25,375-382$.

8. Cabana, V. G., Siegel, J. N. \& Sabesin, S. M. (1989) Effect of acute phase response on the concentration and density distribution of plasma lipids and apolipoproteins. J. Lipid Res. 30, 39-49.

9. Bausserman, L. L., Bernier, D. N., McAdam, K. P. W. J. \& Herbert, P. N. (1988) Serum amyloid A and high density lipoproteins during the acute phase response. Eur. J. Clin. Invest. $18,619-626$.

10. Pepys, M. B. \& Baltz, M. L. (1983) Acute phase proteins with special reference to $C$-reactive protein and related proteins (pentaxius) and serum amyloid A protein. Adv. Immunol. 34, $141-212$.

11. McAdam, K. P. W. J., Elin, R. J., Sipe, J. D. \& Wolff, S. M. (1978) Changes in human serum amyloid A and Creactive protein after etiocholanolone-induced inflammation. J. Clin. Invest. 61, 390-394.

12. Kushner, I., Gewurz, H. \& Benson, M. (1981) C-reactive protein and the acute phase response. J. Lab. Clin. Med. 97, 739-749.

13. Selinger, M. J., McAdam, K. P. W. J., Kaplan, M. M., Sipe, J. D., Vogel, S. N. \& Rosenstreich, D. L. (1980) Monokineinduced synthesis of serum amyloid A protein by hepatocytes. Nature $285,498-500$.

14. McAdam, K. P. W. J., Li, J., Knowles, J., Foss, N. T., Dinarello, C. A., Rosenwasser, L. J., Selinger, M. J., Kaplan, M. M. \& Goodman, R. (1982) The biology of SAA: identification of the inducer, in vitro synthesis, and heterogeneity demonstrated with monoclonal antibodies. Ann. N. Y. Acad. Sci. 389, 126-136.

15. Sipe, J. D. (1978) Induction of the acute phase serum protein SAA requires both RNA and protein synthesis. $\mathrm{Br}$. J. Exp. Pathol. 59, 305-310.

16. Sipe, J. D., Vogel, S. N., Sztein, M. B., Skinner, M. \& Cohen, A. S. (1982) The role of interleukin 1 in acute phase serum amyloid A (SAA) and serum amyloid P (SAP) biosynthesis. Ann. N. Y. Acad. Sci. 389, 137-150.

17. Ramadori, G., Sipe, J. D., Dinarello, C. A., Mizel, S. B. \& Colten, H. R. (1985) Pretranslational of acute phase hepatic protein synthesis by murine recombinant interleukin 1 (IL-1) and purified human IL-1. J. Exp. Med. 162, 930-942.

18. Perlmutter, D. H., Dinarello, C. A., Punsal, P. I. \& Colten, H. R. (1986) Cachectin tumor necrosis factor regulates hepatic acute phase gene expression. J. Clin. Invest. 78, $1349-1354$

19. Moshage, H. J., Roelofs, H. M. J., Van Pelt, J. F., Hazenberg, B. P. C., Van Leeuween, M. A., Limburg, P. C., Aarden, L. A. \& Yap, S. H. (1988) The effect of interleukin1 , interleukin- 6 and its relationship on the synthesis of serum amyloid $\mathrm{A}$ and $\mathrm{C}$-reactive protein in primary cultures of adult human hepatocytes. Biochem. Biophys. Res. Commun. 155, 112-117.

20. Bausserman, L. L., Herbert, P. N. \& McAdam, K. P. W. J. (1980) Heterogeneity of serum amyloid A protein. J. Exp. Med. 152, 641-656.

21. Hoffman, J. S. \& Benditt, E. P. (1982) Changes in high density lipoproteins content following endotoxin administration in the mouse. Formation of serum amyloid-rich subfraction. J. Biol. Chem. 257, 10510-10517.
22. Moon, E. A., Mackinnon, A. M. \& Bacter, P. J. (1984) Appearance of serum amyloid protein in high density lipoproteins of rabbits subjected to relatively mild stimuli. Biochim. Biophys. Acta 796, 354-358.

23. Bausserman, L. L., Saritelli, A. L., Van Zuiden, P., Gollaher, C. J. \& Herbert, P. N. (1987) Degradation of serum amyloid $\mathrm{A}$ by isolated, perfused rat liver. J. Biol. Chem. 262, 1583-1589.

24. Malmendier, C. L., Lontie, J. F. \& Delcroix, C. (1987) In vitro metabolism of apolipoprotein $\mathrm{S}$ in humans. Comparison with apolipoprotein A-I metabolism. Clin. Chim. Acta $170,169-180$.

25. Hoffman, J. S. \& Benditt, E. P. (1983) Plasma clearance kinetics of the amyloid protein (SAA), in the mouse. J. Clin. Invest. 71, 926-934.

26. Bausserman, L. L., Herbert, P. N. \& McAdam, K. P. W. J. (1982) Serum amyloid A polymorphism in subject with a naturally occuring inflammatory response. Clin. Chim. Acta 118, 201-206.

27. Eriksen, N. \& Benditt, E. P. (1984) Trauma, high density lipoproteins, and serum amyloid protein A. Clin. Chim. Acta 140, 139-149.

28. Clifton, P. M., Mackinnon, A. M. \& Barter, P. J. (1985) Effects of serum amyloid A (SAA) on composition, size and density lipoproteins in subjects with myocardial infarction. J. Lipid Res. 26, 1389-1398.

29. Coetzee, G. A., Alidtair, F. S., Westhuyzen, D. R. V., Heinrich, C. H., Jeenah, M. S. \& Beer, F. C. (1986) Serum amyloid A-containing human high density lipoproteins 3 . J. Biol. Chem. 261, 9644-9651.

30. Bienvenu, J., Deshaires, P., Bernon, H., Armanet, P., Peristeris, P., Lepape, A. \& Perdrix, J. P. (1988) Protéine sérique amyloïde A (SAA) et HDL. Implication clinique en réanimation chirurgicale. Ann. Biol. Clin. 46, 343-346.

31. Kabbaj, O., Saile, R., Ghalim, N., Parra, H. J., Puchois, P., Fruchart, J. C., Métais, P. \& Férard, G. (1989) Analyse quantitative des apolipoprotéines et des particules lipoprotéiniques chez les traumatisés crâniens. Ann. Biol. Clin. 47, $35-40$.

32. Havel, R. J., Eder, H. A. \& Bragdon, J. M. (1955) The distribution and chemical composition of ultracentrifugally separated lipoproteins in human plasma. J. Clin. Invest. 34, 1345-1353.

33. Bradford, M. M. (1976) A rapid, and sensitive method for the quantification of microgram quantities of protein utilizing the principle of protein-dye binding. Anal. Biochem. $72,248-254$.

34. Anderson, N. L. \& Anderson, N. J. (1977) High resolution two dimensional electrophoresis of human plasma proteins. Proc. Natl. Acad. Sci. USA 74, $5421-5424$.

35. Sprecher, D. L., Taam, L. \& Brewer, H. B. J. (1984) Two dimensional electrophoresis of human plasma apolipoproteins. Clin. Chem. 30, 2084-2092.

36. Visvikis, S., Steinmetz, J., Cuvelier, I., Galteau, M. M. \& Siest, G. (1986) Study of apo A-I and apo E polymorphism using two dimensional electrophoresis. In Recent progresses in two dimensional electrophoresis (Galteau, M. M. \& Siest, G., eds.) Presses Universitaires de Nancy Publ. pp. 159165

37. Saïle, R., Delpierre, C., Puchois, P., Hocke, G., Cachera, C., Gesquière, J. C., Steinmetz, A., Tartar, A. \& Fruchart, J. C. (1988) Enzyme linked immunosorbent assay for serum amyloid A apolipoprotein with use of specific antibody against synthetic peptides. Clin. Chem. 34, 1767-1771.

38. Parsy, D., Clavey, V., Fievet, C., Kora, I., Duriez, P. \& Fruchart, J. C. (1985) Quantification of apolipoprotein CIII in serum by a non competitive immunoenzymometric assay. Clin. Chem. 31, 1632-1635.

39. Fruchart, J. C., Kora, I., Cachera, C., Clavey, V., Duthilleul, P. \& Moschetto, Y. (1982) Simultaneous measurement of plasma apolipoproteins A-I and B by electroimmunoassay. Clin. Chem. 28, 59-62. 
40. Férard, G., Goester, C., Klumpp, T. \& Métais, P. (1980) An evaluation of immunonephelometry of C-reactive protein in serum. Clin. Chem. 26, 760-761.

41. Odouka, J. \& Férard, G. (1985) Immunonephelometric determination of prealbumin in serum of newborns. Clin. Chem. 31, 486-487.

42. Bausserman, L. L., Herbert, P. N., Forte, T., Klausner, R. D., McAdam, K. P. W. J., Osborne, J. C. \& Rosseneu, M. (1983) Interaction of the serum amyloid A proteins with phospholipid. J. Biol. Chem. 258, $10681-10688$.

43. Edelstein, C., Halari, M. \& Scanu, A. M. (1982) On the mechanism of the displacement of apolipoprotein A-I by apolipoprotein A-II from the high density lipoprotein surface. J. Biol. Chem. 257, 7189-7195.

44. Baumann, H., Jahreis, G. P. \& Gaines, K. C. (1983) Synthesis and regulation of acute phase plasma proteins in primary cultures of mouse hepatocytes. J. Cell. Biol. 97, $866-876$

45. Lowell, C. A., Stearman, R. S. \& Morrow, J. F. (1986) Transcriptional regulation of serum amyloid A gene expression. J. Biol. Chem. 261, 8453-8461.

46. Dimarello, C. A. (1988) Interleukin-1. Rev. Infect. Dis. 6, $51-95$.

47. Castell, J. V., Comez-Lechon, M. J., David, M., Andus, T., Geiger, T., Trullenque, T., Fabra, R. \& Heinrich, P. C. (1989) Interleukin 6 is the major regulator of acute phase synthesis in adult human hepatocytes. FEBS Lett. 242, $237-239$.
48. Marhaug, G., Sletten, K. \& Husby, G. (1982) Characterization of amyloid related protein SAA complexed with serum lipoproteins (apolipoprotein SAA). Clin. Exp. Immunol. 50, 382-389.

49. Eriksen, N. \& Benditt, E. P. (1980) Isolation and characterisation of the amyloid related apoprotein (SAA) from human density lipoprotein. Proc. Natl. Acad. Sci. USA 77, $6860-6864$

50. Bausserman, L. L., Sáritelli, A. L., Herbert, P. N. \& McAdam, K. P. W. J. (1982) $\mathrm{NH}_{2}$-terminal analysis of four of the polymorphism forms of human serum amyloid $\mathrm{A}$ protein. Biochim. Biophys. Acta 704, 556-559.

51. Parmelee, D. C., Titani, K., Ericsson, L. H., Eriksen, N., Benditt, E. P. \& Walsh, K. A. (1982) Amino acid sequence of amyloid-related apoprotein (apo SAA1) from human high density lipoprotein. Biochemistry 21, 3298-3303.

52. Dwulet, F. E., Wallace, D. K. \& Benson, M. D. (1988) Amino acid structures of multiple forms of amyloid-related serum protein SAA from single individual. Biochemistry 27, $1677-1682$.

53. Sipe, J. D., Colten, H. R., Goldberger, G., Edge, M. D., Tack, B. F., Cohen, A. S. \& Whitehead, A. S. (1988) Human serum amyloid A (SAA): biosynthesis and post synthetic processing of preSAA and structural variants defined by complementary DNA. Biochemistry 24, 2931-2936.

54. Kluve-Beckerman, B., Long, G. L. \& Benson, M. D. (1986) DNA sequence evidence for polymorphic forms of human serum amyloid A (SAA). Biochem. Genet. 24, 795-803.

Professor G. Férard

Laboratoire de Biochimie Appliquée UER des Sciences Pharmaceutiques Université Louis Pasteur F-67401 Illkirch Cedex 
